\title{
Castor and jatropha oils: production strategies - A review
}

Regina C.A. LAGO

General Head, Embrapa Food Technology

<lago@ctaa.embrapa.br>

\section{The Brazilian bioenergy program}

In 2003 searching raw materials for biodiesel production the castor oil revival program was launched by the Ministry of Agrarian Development. Small producers in poorer regions, such as northeastern of Brazil were an important motivation for this initiative.

The Brazilian Energy Policy (Law n. 9478/1997) was established with some clear objectives such as: to promote energy security with lesser external dependency, to protect the consumer best interests through regulation mechanisms and surveillance at the Regulatory Agencies, to increase the share of biofuels in the national

\begin{abstract}
The Brazilian bioenergy matrix is based on four platforms: ethanol, energy forests, residues and co-products and biodiesel. The food-energy dichotomy in the use of edible oils is one factor which has stimulated the search for non-edible oleaginous energy crops, such as many native palms. By the year 2000 Brazil had an annual deficit of 80 thousand tons of castor oil, making necessary to import oil from China and India. After a strong debate the National Program on Biodiesel Production (NPBP) was launched by December 2004. After an initial excessive enthusiasm, small producers being focused in the program, a more mature and realistic planning is undertaken. Production in semi arid lands is being stimulated, mainly castor (Ricinus communis) and Jatropha (Jatropha curcas). Apart from belonging to the same botanical family (Euphorbiaceae), both plants are well resistant to poor soils. Castor plant is well adapted to practically the whole country, except for some extreme areas (too low water availability or too much rain). Castor keeps being an alternative for the semi arid region but much more technology is requested to make it largely exploited. Following the petroleum crisis of 1980's an ambitious research program on Jatropha curcas was initiated, later on discontinued and presently retaken by Embrapa and some Universities. Progress is slower than in the case of Ricinus communis. The first agronomical observations confirmed low productivity, problems with pests and diseases, high harvesting costs etc. Some strategic factors should be considered for the production of castor and Jatropha oils: 1. Production of raw materials; 2. Production of oils; 3. Detoxification and value aggregation to the extraction cakes and residues. Regarding raw material production, it is necessary a strong, long term research program on genetic breeding (short cycle varieties, with high productivity and allowing a sole harvesting), soil fertility, pest control, domestication and mechanization. Just to mention Embrapa, in 2007 a new cultivar (BRS Energia) was launched, characterized by low height and single crop per year, thus facilitating mechanized harvesting. In 2009, a new cultivar is expected to be launched, with high tolerance to gray mould, castor principal disease. Concerning oil quality, no significant difference is observed among cultivars, but for biodiesel purposes genetic material with lower ricinoleic acid content is welcomed. The oil production of both species results in nitrogen rich cakes. However, since the cakes contain toxic components making difficult or impeding its production in large scale, total elimination or inactivation of toxic compounds is mandatory before the cakes can be considered useful as animal feed, fertilizer, in waste water pretreatment or any other application. Physical chemical and/or bio detoxification methods are being carried on.
\end{abstract}

Key words: biofuels, biodiesel, sustainability, ricin, phorbol esters

energy matrix, to promote free competition and to protect the environment.

The Brazilian Bioenergy program comprised important premises or concerns including guarantee of internal supply, need of specific taxation model in order to stimulate its usage, expansion of production to supply the growing internal and external demand for ethanol and biodiesel. Transversally to these premises private investments should be stimulated.

In 2006, following the publication of the Brazilian Energy Plan, studies were overtaken which ended by creating a new research centre: Embrapa Agroenergy, now being installed in Brasilia, representing the recognition of the bioenergy importance by the Brazilian Agricultural Research Corporation, Embrapa.
The Brazilian Energy matrix comprises: oil $(38.4 \%)$, biomass $(29.7 \%)$ - where sugar cane occupies $13.9 \%$ and wood/charcoal $13.1 \%$; hydroelectricity $(15.0 \%)$, natural gas (9.3\%), charcoal (6.4\%) and nuclear (1.2\%) (figure 1).

\section{Questions involved in biofuels increasing production}

Environmental gains (such as carbon sequestration and lower level of emissions), economical aspects such as a new global energy demand, renewability (short production cycle of biomass, capability of having the whole process controlled by man), generation of jobs and 


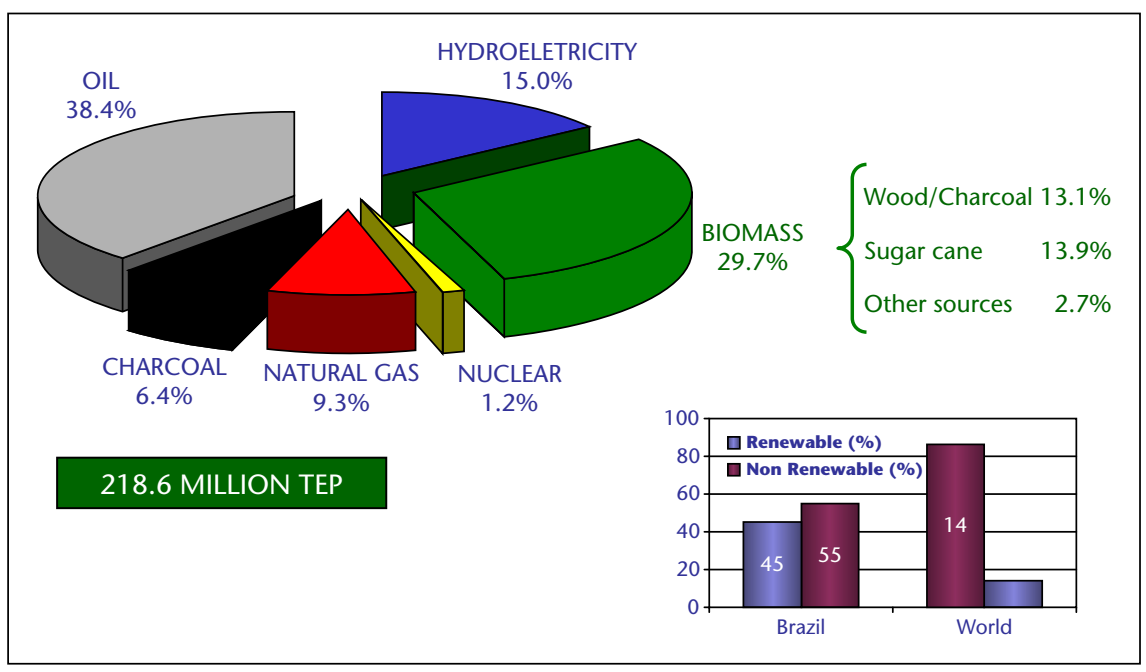

Figure 1. The Brazilian energy matrix. Source: MME, 2006.

better income distribution as the social aspects of the program are important questions behind the idea of producing biofuels.

In Brazil, the use of biofuels meets differential regional motivation (figure 2). The North of the country is constantly submitted to degraded areas reclamation, the access to remote areas is quite difficult thus making important local energy generation as well as energy fuels for boats and prioritization of indigenous plant species (palm species, babassu, etc.). In Center West region, despite the biggest production of soybean there are still areas to be expanded for sugarcane and other energetic crops; transportation of conventional diesel from coastal regions of Brazil is less costing; and conditions for integrating agriculture and animal husbandry are favorable. The Northeast offers possibilities for increasing family agriculture through castor bean production and also for introduction of other energetic cultures such as Jatropha curcas. The region has a great appeal for implementation of government policies of social inclusion. Situation in South/Southeastern regions are different: the air quality in big cities conventional Diesel emissions. Local utilization of soybean and other oleaginous seeds is well established and the integration of agriculture animal husbandry and forest through production systems is a reality.

The Brazilian Agroenergy R\&D program comprises four interconnected platforms: Biodiesel, Ethanol, Energetic Forests and Residues and Co-products, while the guidelines of Agroenergy plan are divided in three axes: agronomic technology development, industrial technology development and transversal studies must be improved through reduction of

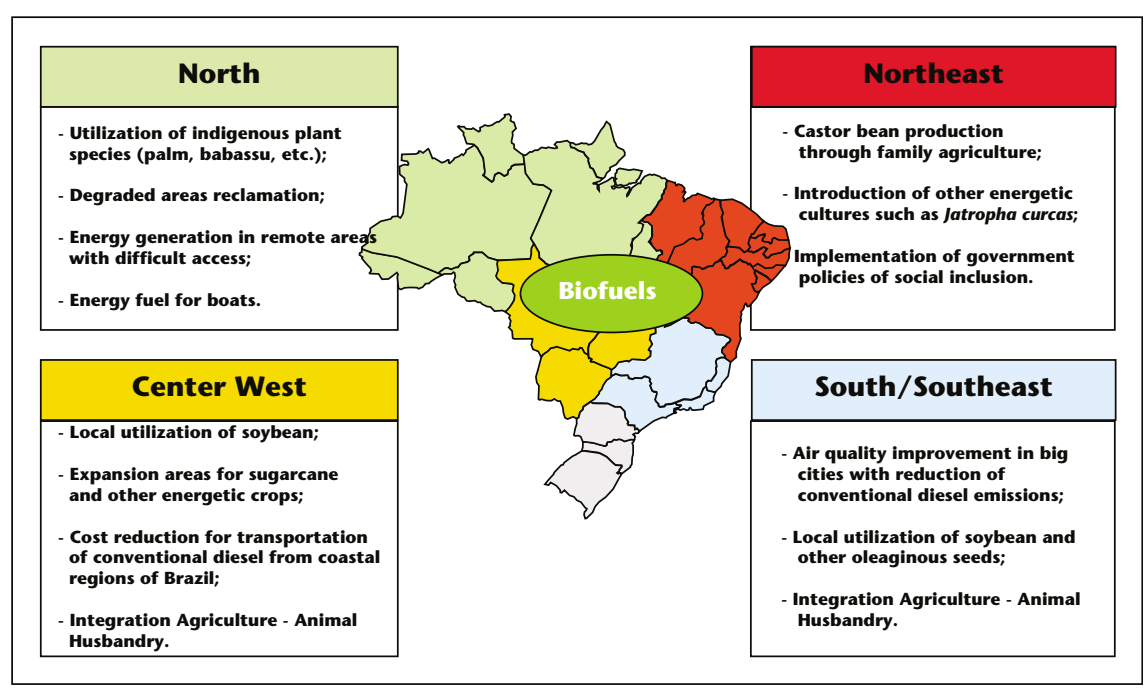

Figure 2. The regional motivation for using biofuels in Brazil. (social, economic, market, management and public policies).

\section{Biodiesel: Regulatory Framework}

Law 11.097/2005 establishes minimum percentages to mix biodiesel to Diesel, and prescribes the need of monitoring the introduction of this new fuel into the market. Initially (20052007) $2 \%$ of biodiesel were authorized to be added to Diesel, requiring potential market of 840 million liters/year. Nowadays the $2 \%$ addition is mandatory and the sound market is of 1 billion liters/year. In 2013, 5\% will be mandatory and this will represent a Sound Market of 2.4 billion liters/year. In 2008, there were produced, in fact, 1.6 billion liters, and the installed capacity fitted a $3 \%$ addition. The actual production of oils in Brazil (table 1) satisfies the volume needed for biodiesel utilization, but for the future should be increased.

Feedstock diversity for biodiesel is represented by soybean, castor, sunflower, palm, cotton and Jatropha (table 2).

Requirements for crop insertion in biodiesel production chain consists of development and establishment of agronomic technology, industrial technology and logistic and infrastructure. Soybean crop fulfills all these requirements while Jatropha none (table 3).

Some other parameters must be fulfilled for incorporating any raw material in the agronomic production chain, such as agronomic zoning, existence of certified materials and seed production infra-structure, including storage and transportation. In Brazil, all these parameters have been established for soybean, just a few for oil palm, sunflower, castor and cotton and none for Jatropha (table 4).

\section{Strategies for expanding biofuels production and mechanisms of sustainability}

The main argument against the use of biofuels is the competition with food production. In Brazil, using degraded areas for expansion and applying rational technology it would not affect food production for domestic consumption. Besides that, the utilization of the coproducts (ex: soybean and sunflower cakes) would complement food supply either for human consumption or animal feed.

In Brazil, 366 billion ha of land are utilized for agronomical activities from a total surface of 851 billion ha. Ninety billion ha $(24.6 \%$ of the total) correspond to non cultivated area still available for expanding agricultural activities. One important date is that sugar cane is cultivated only over 6.2 billion ha correspon- 
Table 1. Brazil: oils and fats (1000 t).

\begin{tabular}{|c|c|c|c|c|c|}
\hline Production & 2003 & 2004 & 2005 & 2006 & 2007 \\
\hline Soybean & 5347.0 & 5546.0 & 5736.0 & 5428.0 & 6046.0 \\
\hline Cottonseed & 217.3 & 264.0 & 256.7 & 241.3 & 259.9 \\
\hline Peanut & 21.8 & 21.8 & 29.4 & 30.2 & 25.2 \\
\hline Sunflower & 23.2 & 28.4 & 22.5 & 30.6 & 39.9 \\
\hline Rapeseed & 20.4 & 225.0 & 27.0 & 39.9 & 37.7 \\
\hline Corn & 55.0 & 63.6 & 71.8 & 75.2 & 79.0 \\
\hline Palm & 129.0 & 142.0 & 160.0 & 170.0 & 190.0 \\
\hline Palmiste & 14.5 & 15.8 & 17.3 & 18.7 & 22.5 \\
\hline Fat Oil & 79.5 & 81.5 & 83.5 & 85.5 & 87.5 \\
\hline Lard & 345.2 & 335.4 & 346.6 & 376.7 & 384.6 \\
\hline Fish & 3.2 & 3.2 & 3.2 & 3.3 & 3.5 \\
\hline Linseed & 2.0 & 2.4 & 3.4 & 3.6 & 3.8 \\
\hline Castor & 39.3 & 55.3 & 70.2 & 48.7 & 43.8 \\
\hline Tallow & 492.6 & 527.6 & 552.1 & 568.3 & 583.8 \\
\hline Total & 6791.9 & 7110.4 & 7381.6 & 7121.9 & 7809.1 \\
\hline
\end{tabular}

Table 2. Feedstock diversity for biodiesel.

\begin{tabular}{|lllcccc|}
\hline Feedstock attributes & Soybean & Sunflower & Castor bean & Cotton & Palm oil $^{*}$ & Jatropha $^{*}$ \\
\hline Average land productivity $\left(\mathrm{kg} \mathrm{ha}^{-1}\right)$ & 3000 & 1500 & 1500 & 3000 & 20,000 & 5000 \\
Seed oil content $(\%)$ & 18 & 42 & 47 & 15 & 20 & 25 \\
Average land oil yield $\left(\mathrm{kg} \mathrm{ha}^{-1}\right)$ & 540 & 630 & 705 & 450 & 4,000 & 1,250 \\
Brazilian harvest in $2005\left(\mathrm{~m}^{3}\right.$ year $\left.^{-1}\right)$ & $56 \times 10^{6}$ & 23,000 & 23,000 & 315,000 & 151,000 & - \\
\hline
\end{tabular}

Palm oil plants: palm, macauba, buriti, inajá, babassu and others *.

Table 3. Requirements for crop insertion in biodiesel production chain.

\begin{tabular}{|c|c|c|c|c|c|}
\hline \multirow[b]{2}{*}{ Raw Material } & \multirow[b]{2}{*}{ Agronomic technology } & \multirow[b]{2}{*}{ Industrial technology } & \multirow[b]{2}{*}{ Logistic and infrastructure } & \multicolumn{2}{|l|}{ Scale } \\
\hline & & & & $\begin{array}{l}\text { Área* } \\
\left(10^{6} \mathrm{ha}\right)\end{array}$ & $\begin{array}{l}\text { Área* } \\
\left(10^{6} \mathrm{ha}\right)\end{array}$ \\
\hline Soybean & $X X X X X X X X X X$ & $X X X X X X X X X X$ & $X X X X X X X X X X$ & 22.00 & 56.00 \\
\hline Palm Oil (Dendê) & $X X X X$ & $X X X X$ & $X X$ & 0.015 & 0.151 \\
\hline Sunflower & $x X X X X$ & $x x x x x$ & $x X X$ & 0.020 & 0.023 \\
\hline Castor bean & $X X X X$ & $X X X X X X$ & $x X$ & 0.120 & 0.090 \\
\hline Cotton & $x X X X X X$ & $X X X X X X$ & $x X X$ & 0.160 & 0.315 \\
\hline Jatropha & - & - & - & - & - \\
\hline
\end{tabular}

*IBGE CONAB 2007/08.

Table 4. Requirements for raw material incorporation into the agronomical production chain.

\begin{tabular}{|lllll|}
\hline Oleaginous Plant & Parameter & & & \\
\cline { 2 - 5 } & Agricultural zoning & Agricultural technology & Certified materials & Seed production infrastructure \\
\hline Soybean & $X X X X$ & $X X X X$ & $X X X X$ & $X X X X$ \\
Castor Bean & $X$ & $X X X$ & $X$ & $X X$ \\
Cotton & $X$ & $X X X$ & $X$ & $X X$ \\
Sunflower & $X$ & $X$ & $X$ & $X$ \\
Palm Oil & $X$ & $X$ & $X$ & $X$ \\
Jatropha & - & - & - & - \\
\hline
\end{tabular}

ding to $1.7 \%$ of the total area suitable for cultivation.

As the objective of biofuels utilization is environmental protection, different mechanisms of sustainability must be taken in account along its production chain.

In Brazil, the no-tillage production system is being used systematically whenever possible, thus protecting the soil and decreasing the use of agrotoxics. Moreover, Embrapa developed a series of production systems integrating crop-livestock and forest and the technologies 
involved are largely sprayed and utilized for either small or big producers. High level of agronomical technology ended up by recuperating degraded pasture as in the Cerrado (savanna) area, where 1 ha recuperated pasture is equal to 1.8 ha of preserved forest.

Also concerning sustainability, optimizing use of areas affected by anthropic action must be overtaken, as the reduction of pressure for slashing fragile or strategic biomes, and the reduction of erosion and water contamination and GG emissions. By other hand, $C$ sequestration and soil biological activity must be increased, and water quality greatly improved.

\section{Some general characteristics of castor plant}

Its tolerance to draught and poor soils and resistance to diseases (development of technology for elimination of grey mould is still in course) are well known. Additionally different production systems were developed involving consortium with food products such as cowpea. Its climatic zoning has been established comprising 23 to $30{ }^{\circ} \mathrm{C}$ and $500 \mathrm{~mm}$ of pluviometry [1].

Relevant research institutions formed a consortium to develop agronomical technology for the plant such as Minas Gerais Agriculture Research Institute, Epamig; Agronomical Institute of Campinas, IAC, and Brazilian Agriculture Research Corporation, Embrapa.

However, castor plant has high intolerance to low $\mathrm{O}_{2}$ incidence and low resistance to certain diseases. Consequently, there is a need for breeding studies in the search of new varieties with annual cycle, which offer potential for mechanization and are highly resistant to pests. In 2009, a new variety resistant to grey mould, will be possibly launched although exclusively for the areas affected by the disease [2].

The factor most discouraging regarding the increase of the castor crop is its low price and productivity and of course its toxicity.

Castor seeds contain 45 to $52 \%$ of oil but the high viscosity of the oil (and consequently of its esters) due to the ricinoleic acid content does not impart to the oil good characteristic for biodiesel performance (table 5). Breeding studies apart from looking for improving agronomical characteristics also take in account the search for material containing less ricinoleic acid as the oil from a wild material that has been reported by Rojas-Barros [3] exhibiting only $10 \%$ of ricinoleic acid.

Protein and other nutrients content in the cake make it an excellent raw material for fertilizer or feed (table 6). However, other factors should also be considered especially for feed application as will be discussed further down.

Table 5. Fatty acid composition of castor seed oil from Brazilian varieties.

\begin{tabular}{|lccccc|}
\hline Fatty Acid & SM-5 & Nordestina & Brejeira & CSRN-393 & CSRD-2 \\
\hline Palmitic & 1.7 & 1.2 & 1.4 & 1.4 & 1.4 \\
Stearic & 1.1 & 1.0 & 1.1 & 1.2 & 1.0 \\
Oleic 9 & 4.4 & 3.5 & 4.0 & 4.3 & 3.1 \\
Oleic 11 & 0.7 & 0.5 & 0.5 & 0.7 & 0.6 \\
Linoleic & 7.5 & 5.1 & 5.3 & 6.0 & 5.8 \\
Linolenic & 0.8 & 0.5 & 0.6 & 0.6 & 0.7 \\
Gadoleic & 0.7 & 0.4 & 0.5 & 0.5 & 0.5 \\
Ricinoleic OH & 82.7 & 87.6 & 86.2 & 84.6 & 86.4 \\
C12 & & & & & \\
\hline
\end{tabular}

Table 6. Cake and shell characterization.

\begin{tabular}{|llcr|}
\hline Cake & \multicolumn{3}{l|}{ Shell } \\
\hline Macronutrients & $\mathbf{( \% )}$ & Macronutrients & $\mathbf{( \% )}$ \\
Nitrogen $(\mathrm{N})$ & 4.0 to 6.0 & Nitrogen $(\mathrm{N})$ & 1.0 \\
Phosphorus $\left(\mathrm{P}_{2} \mathrm{O}_{5}\right)$ & 0.7 to 2.0 & Phosphorus $\left(\mathrm{P}_{2} \mathrm{O}_{5}\right)$ & 0.1 \\
Potassium $\left(\mathrm{K}_{2} \mathrm{O}\right)$ & 1.0 to 2.0 & Potassium $\left(\mathrm{K}_{2} \mathrm{O}\right)$ & 1.9 \\
Calcium $(\mathrm{CaO})$ & 0.5 to 1.8 & Calcium $(\mathrm{CaO})$ & 0.2 \\
Magnesium $(\mathrm{MgO})$ & 0.5 to 0.9 & Magnesium $(\mathrm{MgO})$ & 0.1 \\
Micronutrients & $\mathbf{( p p m )}$ & Micronutrients & $\mathbf{( p p m )}$ \\
Zinc $(\mathrm{Zn})$ & 100 to 141 & Zinc $(\mathrm{Zn})$ & 6 \\
Cuprum $(\mathrm{Cu})$ & 70 to 80 & Cuprum $(\mathrm{Cu})$ & 4 \\
Manganese $(\mathrm{Mn})$ & 55 to 400 & Manganese $(\mathrm{Mn})$ & 69 \\
Iron $(F e)$ & 1.000 to 1.400 & Iron $(\mathrm{Fe})$ & 62 \\
Boro $(\mathrm{B})$ & 80 to 100 & Boron (B) & 18 \\
Other characteristics & & & \\
Moisture & $10 \%$ & & \\
Acid Value & $(\mathrm{pH}) 6.0$ & & \\
Organic matter & $92 \%$ & & \\
Ratio C/N & $6: 1$ a $10: 1$ & & \\
\hline
\end{tabular}

\section{Castor oil extraction}

The processes for extracting castor oil are conventional, either pressing or combining pressing and solvent extraction. The temperatures needed for removal of the solvent reduces the ricin content.

A simultaneous process for extracting the oil and convert it to ethyl esters has been patented by Petrobras researchers [4]. Nevertheless, two plants in operation by Petrobras utilize foreign technology using methanol as the transesterifying alcohol.

Equipment able to de-shell $85 \%$ of the fruits, with an operational capacity of $650 \mathrm{~kg}$ seeds per hour has been adapted, being very useful for small producers (figure 3).

\section{Co-products from castor oil processing}

As shown in table 4 castor cake has excellent composition for fertilizer application. However, castor seeds contain highly toxic and allergenic compounds which severely limit or prevent its use as feed after oil extraction $[5,6]$.
Ricin is a $62-66 \mathrm{kDa}$ protein consisted of two polypeptide chains, approximately $32 \mathrm{kDa}$ and $34 \mathrm{kDa}$ in size, linked by a disulfide bond. The estimated lethal ricin dose in humans is 1$10 \mu \mathrm{g} / \mathrm{kg}[5,7]$.

Additionally, a set of strong allergens known as CB-1A has been described [8]. In Brazil some work has been done on these compounds and lead to the identification of one of them, Ric c 3 [9]. Later one 20 isoforms were described by Machado [10].

The allergenic set is composed by albumins $2 S$, formed by a heavy and a light subunities with molecular mass of 9 and $4 \mathrm{kDa}$, respectively [11]. Biochemical and immunological data relative to nine different fractions of albumins $2 S$, seven of which exhibited allergenic potential has been reported [10].

Table 7 shows some values for oil, ricin and albumin $2 S$ content in some Brazilian castor seeds varieties [12].

Once castor oil production is increased, either provoked by biodiesel or industrial use, a great amount of the cake will inevitably be produced. Even if its final destination is the landfill, it is necessary to eliminate the waste's toxicity and 


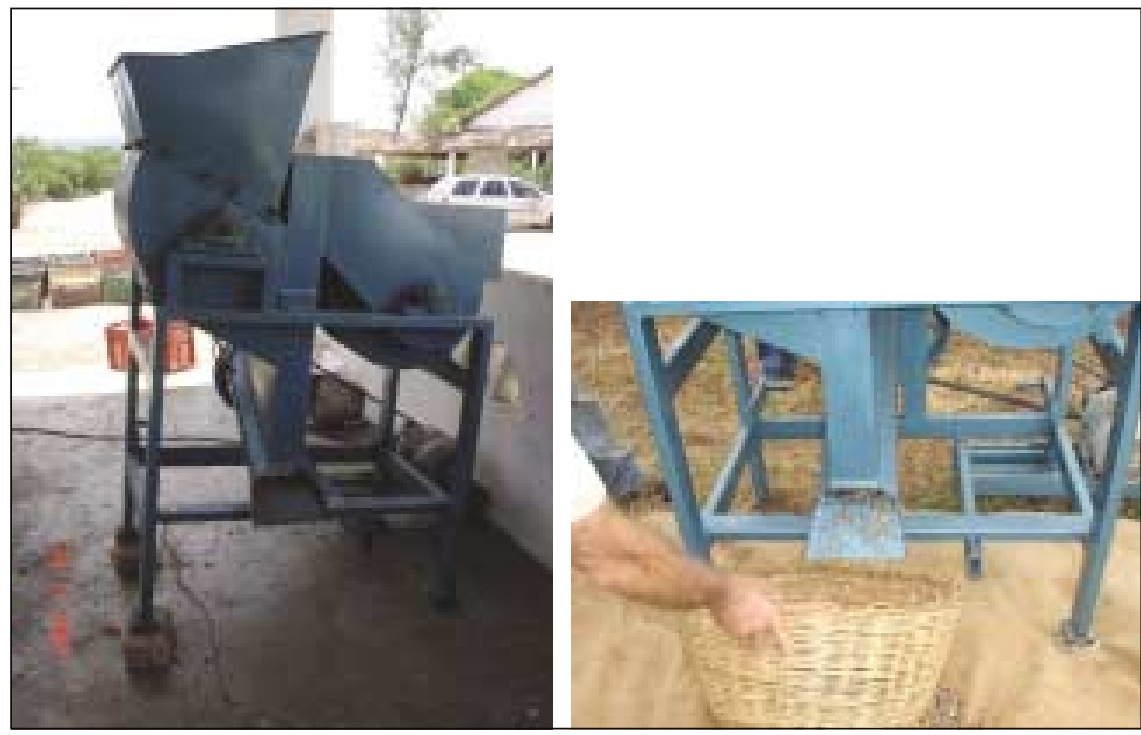

Figure 3. Castor Seeds treatment: the equipment permits deshelling $85 \%$ of the fruits, with an operational capacity of $650 \mathrm{~kg}$ seeds per hour.

avoid contamination of the earth's soil and waters. In any case the cake has to be treated before use.

In Brazil, among other initiatives, two more relevant approaches are being undertaken for detoxification of castor bean and cake. In the first approach, solid-state fermentation (SSF) of castor bean cake was carried out with the lipase produced by Penicillium simplicissimum (maximum activity was $44.8 \mathrm{U} / \mathrm{g}$ ). The fungus $P$. simplicissimum was able to reduce the ricin content to non-detectable levels and to reduce castor bean cake allergenic potential by approximately $16 \%$ [13]. Thermoplastic extrusion is the main tool in the second approach. The technique, in association with 1 or $2 \% \mathrm{CaO}$, already tried by Rhee [14] was carried out to inactivate ricin and simultaneously deactivate allergenic compounds [12]. Ricin was detected by denaturant electrophoresis (SDS-PAGE). For allergenic activity evaluation it was used degranula-

Table 7. Oil content, albumin $2 S$ and ricin in different varieties of castor.

\begin{tabular}{|llll|}
\hline Sample & $\begin{array}{l}\text { Oil } \\
\text { (\%) }\end{array}$ & $\begin{array}{l}\text { Albumin } \\
\text { 2S (\%) }\end{array}$ & $\begin{array}{l}\text { Ricin } \\
\text { (\%) }\end{array}$ \\
\hline BRS Nordestina & 49 & 0.7 & 1.1 \\
BRS Paraguaçu & 48 & 1 & 2.5 \\
IAC-80 & 47 & 0.6 & 1.4 \\
IAC-226 & 47 & 0.5 & 1.6 \\
CNPAM 2000-47 & 46.8 & 1.5 & 4.8 \\
SM Pernambucana & 46.2 & 1.1 & 1.9 \\
CNPAM 2000-72 & 45.1 & 1.6 & 3.5 \\
CNPAM 2000-09 & 44.5 & 1.2 & 3.9 \\
CNPAM 2000-48 & 40.6 & 1.3 & 2.1 \\
\hline
\end{tabular}

Figure 4. Jatropha curcas $L$. ced the 29 and $31 \mathrm{kDa}$ bands content responsible for ricin toxic activity. The treatment with $\mathrm{CaO} 2 \%$ was more efficient since the reduction of degranulation of mastocites (63\% to $47 \%$ ) was superior to the $1 \%$ treatment (63 to 55\%). Extrusion combined with $7 \% \mathrm{CaO}$ was also carried out resulting in total elimination of toxicity and allergenicity. Data are not still available but to find a solution to the problem is essential for the success of biodiesel program.

\section{Some general characteristics of Jatropha curcas $L$}

Belonging to the Euphorbiaceae botanical family, as castor plant does, similarities between the two species should be expected (figure 4). In fact, they are both toxics but for different reasons. Jatropha finds medicinal and veterinary uses and as insecticide but the cake/ meal is non edible as well as the oil which can be used as purgative, for skin treatment and/or biofuel [15].

tion of mastocites, isolated from the peritoneal cavity of rats and then incubated with serum containing $\lg E$ anti-albumins $2 S$, with treated and non treated samples. Degranulation was observed with optical microscopy. The treatment with $\mathrm{CaO} 1$ and $2 \%$ redu-
The data found in literature on agronomical, chemical and technological aspects of Jatropha curcas are very variable. One can attribute this variation to the lack of domesticated varieties. For instance, productivity is reported as going

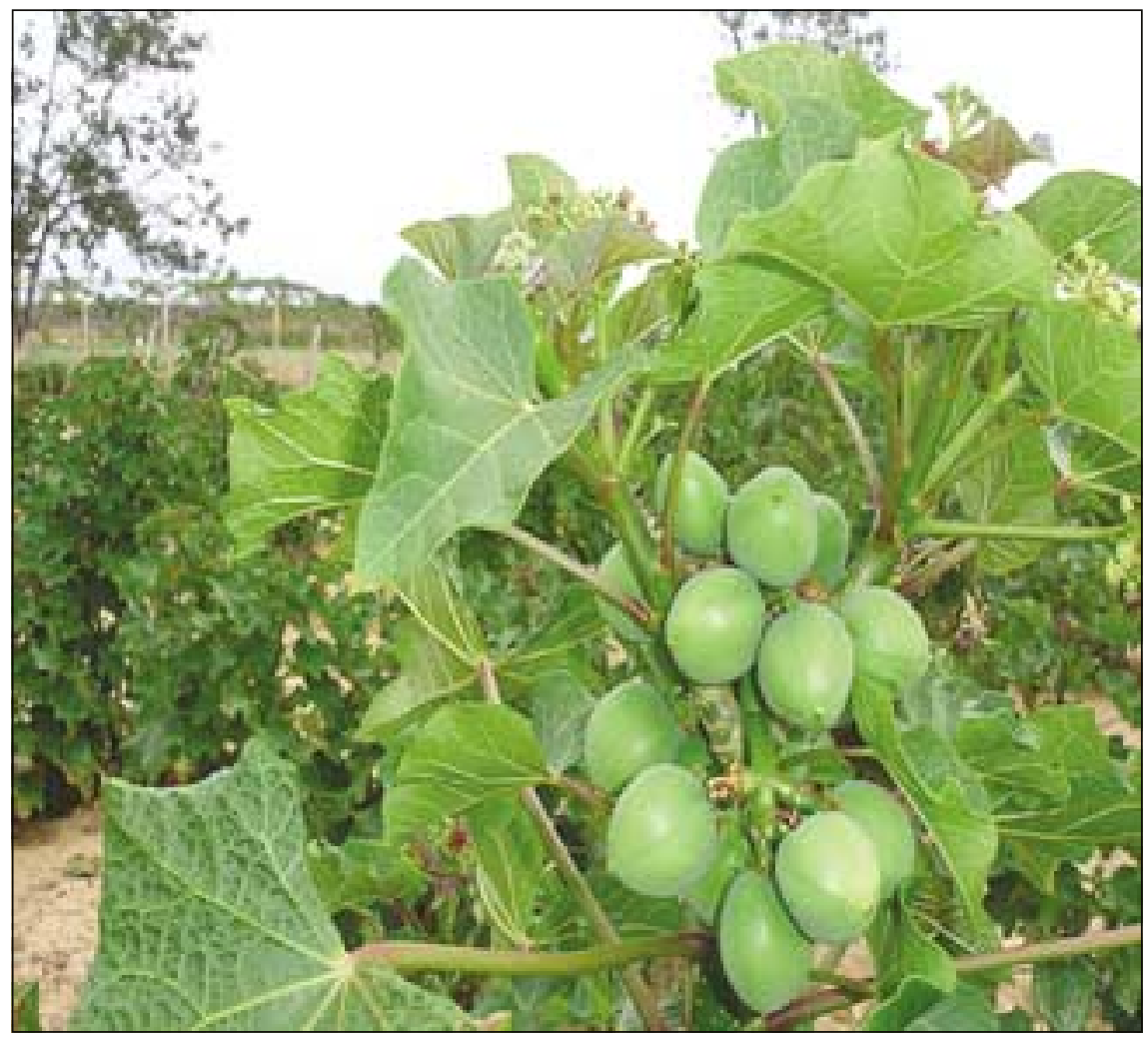


Table 8. Composition of Jatropha Seed and Nut.

\begin{tabular}{|lc|}
\hline Composition & Range (\%) \\
\hline Shell (\% of the seed) & $35.5-47.7$ \\
Nut (\% of the seed) & $50-65$ \\
Oil content in the seed & $24-34$ \\
Nut & \\
Oil content & $46-60$ \\
Protein content & $20-28$ \\
Ash content & $3.8-6.4$ \\
Crude fibre content & $0.9-4.2$ \\
\hline
\end{tabular}

from 2.0 to $12.0 \mathrm{t} / \mathrm{ha}$; oil content ranges from 46 to $60 \%$.

Composition of Jatropha seed and nut is shown in table 8 and of nut, shell and meal in table 9. The possibility of fertilizer utilization is visualized from protein content.

The fatty acid composition of Jatropha curcas seed oil does not pose any problem for its transformation into biodiesel. Distinctly from castor seed oil its main component is oleic acid (34.3 to $45.8 \%$ ), followed by linoleic acid (29 to $44.2 \%$ ) and palmitic acid (14.1 to $15.3 \%)$, some minor constituents from C14:0 to C22:0 and no traces of ricinoleic acid. Martinez-Herrera [16] reports 41.5 to $48.8 \%$ (C18:1), 34.6 to $44.4 \%$ (C18:2), 10.5 to $13.0 \%$ (C14:0).

\section{The context of Jatropha curcas in Brazil}

Despite some agronomical research in the $80 \mathrm{~s}$, Jatropha studies in Brazil are still in its early stages, as shown in tables 3 and 4 . No cultivar has been launched but native plants can be found especially in Minas Gerais where agronomical studies were initiated and new crops are growing in Mato Grosso state (Rural Diesel, Eldorado) (figure 5).

Many challenges are posed by the plant to be overcome before a relevant Jatropha oil production could be settled. Among these are heterogeneous and disperse ripening; broad range of oil content (23 to 35\%); production costs, limited technical knowledge: varieties, pests, diseases; toxicity of the cake and oil. Although tolerant to draught and to low fertility, the plant presents low productivity under these conditions.

Jatropha has been promoted for its ability to grow on marginal lands but until now what we have are wild varieties in the current Jatropha plantations.

Despite the great potential there is tremendous lack of technology for Jatropha development.

Regarding sustainability three aspects should be considered: environmental, social and economical. In the first case the GHG \& energy balance that depends on land use,

Table 9. Jatropha nut, shell and meal composition.

\begin{tabular}{|lccc|}
\hline Constituent & Nut & Shell & Meal \\
\hline Protein & $22-27$ & $4.3-4.5$ & $56.4-63.8$ \\
Oil & $56.8-58.4$ & $0.5-1.4$ & $1.0-1.5$ \\
Ash & $3.6-4.3$ & $2.8-6.1$ & $9.6-10.4$ \\
Neutral Detergent Fibre & $3.5-3.8$ & $83.9-89.4$ & $8.1-9.1$ \\
Acid detergent fibre & $2.4-3.0$ & $74.6-78.3$ & $5.7-7.0$ \\
\hline
\end{tabular}

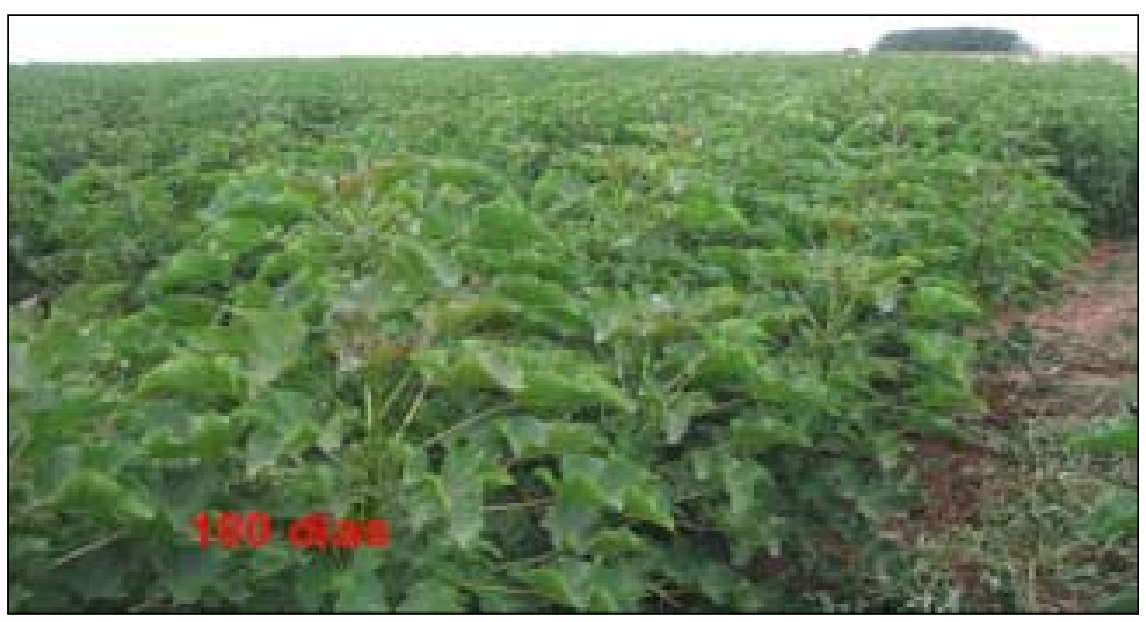

Figure 5. Rural diesel, Eldorado MS.

cultivation intensity and downstream processing. In the social aspect the nondisplacement of food production which is also dependent on land use is of less concern for Brazil as seen before. Nevertheless, related to rural income generation there is a need for more reliable data. In the third aspect reliable income generation is the main parameter which in turn is dependent on oil price and political factors.

In conclusion, more information is needed on energy inputs versus outputs to allow more sustainable practices.

\section{Priorities for Jatropha R\&D}

Brazil has defined the following priorities for Jatropha's R\&D: identify the available varieties using robust genotyping techniques; assess performance of different varieties under different field conditions; monitor crop performance in relation to agricultural inputs; develop varieties with improved agronomic value through plant breeding and develop "nontoxic" varieties as a dual purpose crop (oil and animal feed).

Jatropha meal from "toxic" varieties therefore cannot be used as animal feed, due to its tumour promoting activity i.e., its influence on the increase incidence of tumour formation in the presence of carcinogens [17].

\section{Strategies for increasing Jatropha's production}

Embrapa is part of a pool of 30 research institutions, comprising 98 researchers conducting 126 R\&D\&I activities on Jatropha for 20082011 period. The investments involved go up to US\$3.500.000. And the main goals for this pool are: establish and characterize Jatropha germoplasm banks; establish and validate production systems (agronomical technology); develop new varieties; develop studies for feasibility and sustainability in the production chain and detoxification and new uses for co-products.

\section{Antinutritional and toxic compounds removal}

Apparently, detoxification task for Jatropha is harder than in castor due to a greater number of toxic and antinutritional compounds and to the fact that they are more spread out in the products resulting from oil extraction. Among these are curcin (protein similar to ricin), phorbol esters (variable content), lectins, phytates, trypsin 
inhibitor and saponins. Makkar [18], gives a comprehensive report on the analysis of some of these compounds.

Phorbol esters are analogues of diacylglycerol, activate protein kinase $C$ (PKC) and are acutely toxic (even though they present quite different biological activities and chemical stabilities) and thermostable. They are partially removed during oil extraction but the efficiency of the process depends on the type of extraction, solvent extraction being more efficient than pressing. In the case of solvent extraction the removal of phorbol esters will depend on the solvent type and subsequent treatment [19].

In Brazil, research for detoxification of Jatropha seeds is in its early stages.

\section{Perspectives}

The future is very promising for Jatropha breeding - there is substantial variation and we can benefit from new technologies and "piggy-back" on knowledge gained from other crops to go after specific traits such as yield, architecture and disease resistance. Robust standards for describing genetic variation and "new" elite lines are needed. A network of evaluation of elite genotypes of Jatropha curcas has been settled whose objective is to evaluate and select elite genotypes of Jatropha curcas adapted to different producing areas in Brazil. The assays comprise 20 genotypes in 6 areas of $0.3 \mathrm{ha} /$ area (DF, PE, MS, RS, RJ, MG). First new variety is expected to be launched in 2011.

A lot of work has to be done and we should set ourselves challenging targets for "rapid domestication" of Jatropha and work together to achieve these for the benefit of all.

Acknowledgement. To Humberto R. Bizzo, Jose Luis Ascheri, Carlos Wanderley P. Carvalho and Rosemar Antoniassi (Embrapa Food Technology); Esdras Sundfeld (Embrapa Agroenergy);
João Flavio Veloso (Embrapa Mato Grosso); Liv Severino (Embrapa Cotton) and Elisa D. C. Cavalcanti (IQ/UFRJ) for valuable information and collaboration.

\section{REFERENCES}

1. Beltrão NEM. http://www.cnpa.embrapa.br/ produtos/mamona/index.html, 2004.

2. Severino LS. Personal communication, 2009.

3. Rojas-Barros P, de Haro A, Muñoz J, FernándezMartínez JM. Isolation of a Natural Mutant in Castor with High Oleic/Low Ricinoleic Acid Content in the Oil. Crop Sci $2004 ; 44$ : 76-80.

4. Khalil CN, Leite, L. Process for producing biodiesel fuel using triglyceride-rich oleaginous seed directly in a transesterification reaction in the presence of an alkaline alkoxide catalyst. 2006. US Patent 7112229.

5. Audi J, Belson M, Patel M, Shier J, Osterloh J. Ricin poisoning - A comprehensive review. J Am Medical Assoc 2005 ; 294 : 2342-51.

6. Thorpe SC, Kemeny DM, Panzani RC, Mcgurl B, Lord M. Allergy to castor bean. II. Identification of the major allergens in castor bean-seeds. J Allergy Clin Immunol $1988 ; 21$ : 67-72.

7. Rao PVL, Jayaraj R, Bhaskar ASB, Kumar O, Bhattacharya R, Saxena P. Mechanism of ricininduced apoptosis in human cervical cancer cells. Biochem Pharmacol $2005 ; 69$ : 855-65.

8. Spies JR, Coulson EJ. The chemistry of allergens. VIII. Isolation and properties of an active protein-polysaccharide fraction CB-IA, from castor beans. J Am Chem Soc 1943; 65: 1720-5.

9. Machado OLT, Silva Jr JG. An allergenic 25 storage protein from Ricinus communis seeds which is a part of the $2 S$ albumin precursor predicted by c-DNA data. Braz I of Medical and Biological Research $1992 ; 25$ : 567-82.

10. Machado OLT, Marcondes JA, De Souza-Silva F, et al. Characterization of allergenic $2 S$ albumin isoforms from Ricinus communis seeds. Allergologie / 2003 ; 26 : 45-51.
11. Thoyts PJE, Napier JA, Millichip M, et al. Characterisation of a sunflower seed albumin which associates with oil bodies. Plant Science 1996; $118: 119-26$.

12. Ascheri, JLR, Maciel, FM, Carvalho CWP, Freitas SC, Machado OLT. Detoxificação da torta de mamona por extrusão termoplástica: Estudo preliminar. In: /I Congresso da Rede Brasileira de Tecnologia de Biodiesel, 2007, Brasília. Anais do II Congresso da Rede Brasileira de Tecnologia de Biodiesel, 2007. CDRom.

13. Godoy MG, Gutarra MLE, Maciel FM, et al. Use of a low-cost methodology for biodetoxification of castor bean waste and lipase production. Enzyme and Microbial Technology 2009; $44: 317-22$.

14. Rhee KC. Production of non toxic bean meal free of allergens. Vienna, Austria : United Nations Industrial Development Organization, 1987.

15. Adebowale KO, Adedire CO. Chemical composition and insecticidal properties of the underutilized Jatropha curcas seed oil. African J of Biotechnology $2006 ; 5$ : 901-9.

16. Martinez-Herrera J, Siddhuraju P, Francis $G$, Dávila-Ortiz G, Becker K. Chemical composition, toxic/antimetabolic constituents, and effects of different treatments on their levels, in four provenances of Jatropha curcas L. from Mexico. Food Chemistry 2006 ; 96 : 80-9.

17. Hirota $M$, Suttajit $M$, Suguri $H$, et al. A new tumour promoter from the seed oil of Jatropha curcas L., an intramolecular diester of 12 deoxy-16-hydroxyphorbol. Cancer Res 1988 ; $48: 5800-4$.

18. Makkar HPS, Becker K, Sporer F, Wink M. Studies on nutritive potential and toxic constituents of different provenances of Jatropha curcas. J Agric Food Chem 1997; 45 : 3152-7.

19. Haas W, Mittelbach M. Detoxification experiments with the seed oil from Jatropha curcas L. Industrial Crops and Products $2000 ; 12$ : 111-8. 